\title{
APPLICATION OF ALKALINE SULFITE PULPING ON CORN STALKS
}

\begin{abstract}
Ahmad Jahan Latibari, ${ }^{\mathrm{a}, *}$ Mohammad Ali Hossein, ${ }^{\mathrm{a}}$ Reza Hosseinpour ${ }^{\mathrm{a}}$
Alkaline sulfite pulping of corn stalks was investigated to produce supplementary pulp for corrugating board manufacture. Three pulping temperatures $\left(125,145\right.$, and $\left.165^{\circ} \mathrm{C}\right)$ and five active alkali charges $(10,12,14,16$, and 18\%) were used. Cooking time at 30 minutes, $\mathrm{Na}_{2} \mathrm{SO}_{3} / \mathrm{NaOH}$ ratio at 50:50, and liquor to residue ratio of 8:1 were kept constant. The highest total yield $(61.9 \%)$ was reached applying the treatment combination of $125^{\circ} \mathrm{C}$ and $10 \%$ active alkali, and the lowest total yield $(42.5 \%)$ was related to $165^{\circ} \mathrm{C}$ and $16 \%$ chemical. The influence of sodium sulfite/sodium hydroxide ratios was studied applying different ratios (30:70, 40:60, 50:50, 60:40, and 70:30) at constant time and temperature of 30 minutes and $145^{\circ} \mathrm{C}$ respectively and 14 and $16 \%$ active alkali. Pulping condition; $16 \%$ active alkali, 30 minutes time, $145^{\circ} \mathrm{C}$ pulping temperature and varying ratios of sodium sulfite/sodium hydroxide were selected for pulp strength evaluation. The results of handsheet evaluation indicated that $16 \%$ active alkali, 30 minutes pulping at $145^{\circ} \mathrm{C}$ and sodium sulfite/sodium hydroxide ratio of 50:50 is the optimum pulping condition for corn stalks. Tear, tensile, and burst indices and breaking length of this pulp were measured as $10.53 \mathrm{mN} \cdot \mathrm{m}^{2} \mathrm{~g}^{-1}, 62.4 \mathrm{~N} \cdot \mathrm{mg}^{-1}$, $3.80 \mathrm{kPa} \cdot \mathrm{m}^{2} \mathrm{~g}^{-1}$, and $6.07 \mathrm{~km}$, respectively.
\end{abstract}

Keywords: Corn; Alkaline sulfite; Soda; Yield; Strength

Contact information: a: Agriculture Research Center, College of Agriculture and Natural Resources, Islamic Azad University, Karadj Branch, Karadj, Iran, Azadi Ave. Eram Blvd. Mehrshahr, Karadj, IRAN. *Corresponding author: latibari_24@yahoo.com

\section{INTRODUCTION}

Recent trends in global paper production show that more and more countries are willing and trying to establish pulp and paper production facilities to satisfy their national demands. In such situation, countries and regions with limited paper production also try to develop national and domestic capacities, preferably based on local raw materials, which may be unconventional. Of course, such attempts are not limited to fiber-deficient regions. Fiber-rich countries are also searching for alternative raw materials to replace or supplement hardwood fiber sources (McKean and Jacobs 1997). Consequently annual plant pulping has found more and more importance, especially in fiber-deficient regions, and since 1970 the non-wood plant fiber pulping capacities have increased two to three times as fast as wood pulping capacity on a global basis (Hedjazi et al. 2009). Recently Pande (2009) proposed three scenarios in the area of non-wood pulping. In scenario 1, non-wood pulping capacity was projected to increase from 20.736 million metric tons (Mtons) in 1993 to 36.484 Mtons in 2010 considering the basis that the present non-wood pulping rate would be saved and that those countries then practicing non-wood pulping would continue the production. According to scenario 2; non-wood pulp production would 
increase to 84.805 Mtons in 2010. In this scenario, non-wood pulping rate in countries that were currently producing non wood pulps would increase and regions such as North America, Latin America as well as Africa will produce up to 5\% of their pulp requirement utilizing non-wood fibers. In a third scenario, the lowest nonwood pulping was considered, and the non-wood pulping would be limited to 35.624 Mtons in 2010.

However, during the late $20^{\text {th }}$ century a global shortage of wood has emerged, and consequently the paper industry was forced to look for alternatives sources of fibrous raw material. The fiber supply in regions such as Asia and the Middle East is so restricted that these locations have concentrated on utilization of non-woods as raw material. Therefore, it is believed that the non-wood pulp production will gain momentum at an annual rate between 12 and $15 \%$, even though it seems unrealistic. In this expansion path, the share of undeveloped countries which are faced with wood fiber supply limitation will be more than fiber-rich countries.

Such large increases in non-wood pulp production have motivated research activities worldwide, and various research groups have initiated projects to develop, improve, and implement non-wood pulping. Such research covers a wide range of processes from conventional soda pulping of bagasse and cereal straw to nonconventional fibers such as date palm residues (Kristova et al. 2005). Various alternative pulping methods, including neutral sulfite pulping of wheat straw (Ali et al. 1991), different pulping of wheat straw (Ates et al. 2008), and Soda/AQ, Alkaline Sulfite/AQ, and ASAM pulping of date palm residues (Khristova et al. 2005) have been investigated. Other pulping activities have been studied to increase the pulping yield. Wheat straw Alkaline Peroxide Mechanical Pulping (APMP) (Pan and Leary 2002) and APMP pulping of bagasse and kenaf (Xu and Rao 2001) and chemimechanical pulping of kenaf (Law et al. 2003) are examples.

To produce corn grains to fulfill the needs of societies worldwide, vast areas are under corn cultivation. Such activities generate large quantities of residues, which are mostly unused. Even though in some locations it is used as cattle feed, its nutrition value is not sufficient. However, its geographic concentration favors industrial applications such as pulping on a small scale, as practiced in countries such as Iran, Pakistan, and Egypt, or for chemical feedstock production.

Even though the first attempt of corn stalks pulping was initiated in 1837 to produce paperboard and packaging paper pulp in Europe, especially in Austria, followed by the work of Weber in 1929, research was terminated soon due to unfavorable results (MacGovern et al. 1987). Recently, Byrd and Hurter (2005), in an attempt at simplification, applied a newly developed pulping process (EAZP, Extraction-Acid chelating-Ozone-Peroxide) on undepithed corn stalks to produce bleached pulp. Although the optical and strength characteristic of pulp were good, the overall bleached pulp yield was limited to $38 \%$.

The present investigation attempts to develop a simple pulping process for corn stalk and to characterize the pulp properties to be utilized as supplementary pulp for small scale paper mills. For annual plants, mostly soda pulping has been used. Soda pulping is a well-established process that is able to process vast variety of annual plant raw material, but this process has particular disadvantages as well. Strong alkaline pulping liquor decomposes carbohydrates by peeling reactions and alkaline hydrolysis. Sodium hydroxide easily dissolves phenolic lignin structures, and in non-phenolic lignin moieties only beta-ethers are cleaved. Under strongly alkaline 
conditions, lignin undergoes condensation reactions, which reduce the reactivity of the residual lignin. In addition, annual plants contain fairly high silica, and strongly alkaline cooking liquors dissolve it to a great extent. The dissolved silica creates mainly precipitation problems in evaporators, recovery boilers, and in the causticising plant.

By contrast, there have been only limited studies on the usage of sulfite compounds in the pulping of annual plants (Hedjazi et al. 2009). Pulping of different hardwoods and agricultural residues including wheat straw, elephant grass, bagasse, and sorghum were investigated applying ASAM pulping (Kordsachia and Patt 1991). The results indicated that compared to the conventional soda, ASAM pulping of agricultural residues showed better delignification, improved yield, and higher brightness of unbleached pulp. The ash content, especially the silica content, of the ASAM pulp was higher due to the less alkaline pulping conditions, reducing the silica content in pulping liquor and thereby reducing recovery problems caused by silicate precipitation. Alkaline sulfate/AQ pulping and totally chlorine free bleaching was applied on wheat straw, rice straw, and bagasse to develop an alternative pulping for these materials (Hedjazi et al. 2008a, 2008b, 2009). Therefore, to overcome the drawback of low pulping yield, which is inherent to corn stalks, and to produce satisfactory pulp at higher yield, alkaline sulfite pulping was studied. Selected soda pulps were also produced for comparison. The corn stalks pulp properties were compared with those of other non-wood pulps reported in the literature.

\section{EXPERIMENTAL}

\section{Material}

Corn stalks were collected from Agriculture and Natural Resources College Experimental Station, Islamic Azad University, Karadj Branch. Samples were cleaned, leaves and debris were separated, and then stalks were depithed manually by hand. Depithed material was chopped into 2 to 4 centimeter length chips. Chips were dried at ambient temperature and after reaching equilibrium moisture, chips were stored in plastic bags until used.

\section{Fiber Dimension and Chemical Analysis}

Small pieces of stalks were defibrated using the technique developed by Franklin (1954), and then the dimensions of 100 fibers were measured using projection microscope and the average of measurement was calculated.

Relevant TAPPI test methods were used for chemical analysis as follows: Ash, T211-om 93; Extractives soluble in alcohol-acetone, T207-om 97; Extractive-free powder, T264-om 97; Cellulose, T264-om 88; Lignin, T222-om 97; and 1\% $\mathrm{NaOH}$ solubility, T212-om 98.

\section{Pulping}

Experimental conditions were set as follows:

Five levels of active alkali $\left(10,12,14,16\right.$, and $18 \%$, based on $\left.\mathrm{Na}_{2} \mathrm{O}\right)$, three pulping temperatures $\left(125,145\right.$, and $\left.165{ }^{\circ} \mathrm{C}\right)$, and five ratios of sodium sulfite to sodium hydroxide (30:70, 40:60, 50:50, 60:40, and 70:30) were studied. Pulping time was kept constant as 30 minutes. Soda pulps applying different active alkali of 12, 14, 
16 , and $18 \%\left(\mathrm{Na}_{2} \mathrm{O}\right.$ basis $)$ and constant pulping time and temperature of 15 minutes and $145^{\circ} \mathrm{C}$ respectively were also made. For each combination of variables, three replica pulps were prepared.

All cooks were performed in a 4 liter rotating digester "Ghomes Wood and Paper Equipment Manufacturing Co." using $100 \mathrm{~g}$ of corn stalks chips (dry basis). At the end of each cook, the contents of the cylinder were discharged on a 200 mesh screen, and the cooked material was washed using hot water. The remaining liquor was separated by hand pressing the cooked material. The cooked material was defibrated using a $25 \mathrm{~cm}$ laboratory single disc refiner, and then the pulp was screened using a set of two screens, a 14-mesh screen on top of 200 mesh screens. Material remained on the 14-mesh screen was considered as rejected (shives), and the fibers that passed the 14-mesh screen and remained on the 200-mesh screen were considered as accepted pulp (screened yield).

The following TAPPI test methods were used for pulp analysis: Kappa number, T236 om-99; Beating, T248 om-88; Freeness, T227 om-99; Handsheet preparation, T205 om-95; Tear strength, T414 om-04; Tensile strength and breaking length, T494 om-92; and burst strength, T403 om-02.

\section{RESULTS}

\section{Chemical Composition and Fiber Dimensions}

The following chemical levels of chemical components were determined: cellulose, 51.2\%; lignin, 23\%; extractives soluble in alcohol and acetone, 15\%; $1 \%$ $\mathrm{NaOH}$ solubles, $45.9 \%$; and ash, $2.06 \%$. The fiber dimension including fiber length, fiber width, and cell wall thickness were determined as $1.03 \mathrm{~mm}, 23.63 \mu \mathrm{m}$, and 3.5 $\mu \mathrm{m}$, respectively.

\section{Pulping}

A limited number of research reports is available on corn stalks pulping. The most recent available report is on EAZP pulping of pith containing corn stalks with the aim of developing a simplified pulping technology to produce bleached pulp (Byrd and Hurter 2005). Even though promising results were reached, the overall bleached pulp yield was limited to $38 \%$. Also, contrary to the claim that it was attempted to develop a simple pulping method, four stages of pulping including three or four stage bleaching makes this pulping process too complicated and unpractical for use on a small scale in undeveloped locations that are suffering from wood shortage and ought to rely on non-wood sources such as corn stalks. In this study, we concentrated on the development of a simple pulping to produce pulp on small scale suitable as supplementary pulp for brown paper production. Alkaline sulfite pulping has been successfully applied on non-wood plant fibers and the outcome is promising (Hedjazi et al. 2008a; 2008b; 2009).

To optimize the alkaline sulfite (AS) pulping conditions for corn stalks and because of unknown behavior of this material, we had to select different chemical charge and temperatures as well as sodium sulfite/sodium hydroxide ratios. However, to avoid too many pulping trails, it was decided to perform the pulping in two stages. In the first stage, the influence of alkali charge and cooking temperatures were studied. Even though it is known that in non-wood plant fibers alkaline sulfite 
pulping, the charge of sodium sulfite predominates, in this stage a sodium hydroxide/ sodium sulfite ratio of 50/50 was selected. The results of pulping trials, including yield and kappa number are summarized in Table 1. Data on soda pulping of corn stalks applying different alkali charge are also shown in Table 1.

Table 1. Alkaline Sulfite (AS) Pulping (pulping time; 30 minutes and sodium sulfite/sodium hydroxide ratio; 50/50) and Soda (S) Pulping (pulping time; 15 minutes) Conditions and the Resulting Pulp Yield and Kappa Number

\begin{tabular}{|c|c|c|c|c|c|}
\hline \multirow[b]{2}{*}{ Trial No. } & \multirow{2}{*}{$\begin{array}{c}\text { Pulping } \\
\text { Temperature } \\
\left({ }^{\circ} \mathrm{C}\right)\end{array}$} & \multirow{2}{*}{$\begin{array}{c}\text { Active Alkali } \\
\text { charge } \\
(\%)\end{array}$} & \multicolumn{2}{|c|}{ Yield (\%) } & \multirow{2}{*}{$\begin{array}{c}\text { Kappa } \\
\text { number }\end{array}$} \\
\hline & & & Screened & Total & \\
\hline AS1 & 125 & 10 & 48.1 & 61.9 & 60.7 \\
\hline AS2 & 125 & 12 & 45.4 & 54.7 & 47.7 \\
\hline AS3 & 125 & 14 & 43.9 & 52.1 & 45.5 \\
\hline AS4 & 125 & 16 & 47.8 & 53.3 & 37.9 \\
\hline AS5 & 125 & 18 & 48.4 & 50.6 & 37.4 \\
\hline AS6 & 145 & 10 & 48.6 & 54.5 & 53.1 \\
\hline AS7 & 145 & 12 & 52.2 & 55.4 & 45.3 \\
\hline AS8 & 145 & 14 & 51.2 & 53.7 & 28.1 \\
\hline AS9 & 145 & 16 & 50.5 & 52.2 & 26.6 \\
\hline AS10 & 145 & 18 & 49.4 & 51.1 & 24.9 \\
\hline AS11 & 165 & 10 & 50.4 & 52.3 & 56.2 \\
\hline AS12 & 165 & 12 & 49.4 & 50.5 & 37.1 \\
\hline AS13 & 165 & 14 & 45.8 & 46.4 & 32.1 \\
\hline AS14 & 165 & 16 & 42.2 & 42.5 & 25.4 \\
\hline AS15 & 165 & 18 & 42.4 & 42.7 & 26.4 \\
\hline S1 & 145 & 12 & 37.5 & 43.2 & 57.9 \\
\hline $\mathrm{S} 2$ & 145 & 14 & 37.6 & 41 & 46.2 \\
\hline S3 & 145 & 16 & 39.6 & 41.4 & 33.9 \\
\hline S4 & 145 & 18 & 39.6 & 40 & 23.1 \\
\hline Wheat straw $\mathrm{CMP}^{1}$ & & 6.6 & - & 66 & - \\
\hline Canola, Soda ${ }^{2}$ & & 22 & 36.6 & 36.9 & 24.2 \\
\hline Corn EAZP (E-stage) ${ }^{3}$ & & 14 & - & 57.9 & 20.1 \\
\hline Corn Soda/AQ ${ }^{3}$ & & 16 & 43.5 & 55.1 & 32.9 \\
\hline
\end{tabular}

1- Petit-Conil et al. 2001

2- Enayati et al. 2009

3- Byrd and Hurter 2005

The results in Table 1 indicate that the pulping yield was low and kappa number was high, which is inherent to corn stalk, attributed to its very high solubility in $1 \% \mathrm{NaOH}(45.9 \%)$ and high lignin content $(23 \%)$. This is in accordance to other research efforts, not for alkaline sulfite pulping, but for either soda or kraft pulping. MacGovern et al. (1987) reported that the soda pulping yield of corn stalk is limited to $36.9 \%$ to $39.6 \%$ and the more recent work by Byrd and Hurter (2005) showed that the E-stage (alkali extraction applying 14\% NaOH based oven dry weight of whole corn stalks, and cooking at $118^{\circ} \mathrm{C}$ for 60 minutes) total yield was limited to $57.9 \%$ at 20.1 kappa number, without mentioning the rejects. Jahan Latibari et al. (1996) measured the total yield of soda pulp from corn stalks as 40.5\% (kappa number of 64.9) and kraft pulp as $47.5 \%$ (kappa number of 73.5 ). The impact of pulping temperature and chemical charge revealed that if either variable increases, both total yield and kappa number decreases. Nevertheless, at lower chemical charge, the total yield is higher, 
but the amount of reject is also high. However, at higher pulping temperatures, both total yield and rejects decrease. It is evident that corn stalks are vulnerable to pulping temperature, and at higher temperatures the yield is reduced at a faster rate than kappa number, indicating the degradation of carbohydrates. Therefore, pulping temperature must be limited to $145^{\circ} \mathrm{C}$ to reach an acceptable balance between the yield and kappa number. Comparison of the total yield of alkaline sulfite and soda pulps from corn stalks revealed higher yield and lower kappa number of alkaline sulfite pulp at identical alkali charge. Despite this, the pulping yield of alkaline sulfite pulp from corn stalks was lower than anticipated, and it was lower than CMP from wheat straw (Petit-Conil 2001), but it was higher than canola soda (Enayati et al. 2009) as well as corn stalks soda/AQ ( Byrd and Hurter 2005) (Table 1).

Based on the analysis of first stage pulping results, considering the pulping yield and kappa number (Table 1), pulping conditions including pulping temperature of $145^{\circ} \mathrm{C}$ and active alkali of 14 and $16 \%$ were selected for further pulping (trials no. AS8 and AS9). Trials no. AS14-AS15 showed identical or slightly lower kappa number, but the total yield was limited to 42.5 to $42.7 \%$, compared to higher total yield of trials no. AS8 and AS9. Alkaline sulfite pulping of other non-wood plant fibers had demonstrated that as the ratio of sodium sulfite/sodium hydroxide varies, pulping performance changes (Hedjazi et al. 2009). At higher ratios, the pulping yield and brightness improve, but at the cost of higher reject (Wang \& Patt 1989; Kristova et al. 2002; Braunstien 2002). Therefore, to investigate the influence of sodium sulfite/sodium hydroxide ratio on pulping yield and kappa number (delignification efficiencies), different ratios of sodium sulfite/sodium hydroxide were studied at two active alkali charges of 14 and $16 \%$. The pulping results of this stage (Table 2) demonstrated the influence of sodium sulfite/sodium hydroxide ratio on delignification efficiency. At higher rate of sodium sulfite charge, both total yield and kappa number increased (trials no. SN5 and SN10), which is the consequence of carbohydrate preservation. This indicates better delignification potential of sodium hydroxide at similar alkalinity and probably better strength of the resulting pulp.

Table 2. The Influence of Active Alkali and Sodium Sulfite/Sodium Hydroxide Ratio on Pulping Yield and Kappa Number (pulping time: 30 minutes; pulping temperature: $145^{\circ} \mathrm{C}$ )

\begin{tabular}{|c|c|c|c|c|c|c|c|c|}
\hline \multirow{2}{*}{$\begin{array}{l}\text { Trial } \\
\text { No. }\end{array}$} & \multirow{2}{*}{$\begin{array}{c}\text { Active Alkali } \\
(\%)^{*}\end{array}$} & \multicolumn{2}{|c|}{ Chemical Ratio } & \multicolumn{2}{|c|}{ Residual Chemical } & \multicolumn{2}{|c|}{ Yield (\%) } & \multirow{2}{*}{$\begin{array}{c}\text { Kappa } \\
\text { Number }\end{array}$} \\
\hline & & $\begin{array}{c}\mathrm{Na}_{2} \mathrm{SO}_{3} \\
(\%)^{*}\end{array}$ & $\begin{array}{c}\mathrm{NaOH} \\
(\%)^{*}\end{array}$ & $\begin{array}{l}\mathrm{Na}_{2} \mathrm{SO}_{3} \\
(\%)^{*}\end{array}$ & $\begin{array}{l}\mathrm{NaOH} \\
(\%)^{*}\end{array}$ & Screened & Total & \\
\hline SN1 & 14 & 30 & 70 & 0.6 & 0.88 & 45 & 49.4 & 30.8 \\
\hline SN2 & 14 & 40 & 60 & 0.57 & 0.66 & 43.2 & 49.5 & 33.3 \\
\hline SN3 & 14 & 50 & 50 & 1.29 & 0.51 & 45.2 & 50.6 & 33.9 \\
\hline SN4 & 14 & 60 & 40 & 1.45 & 0.21 & 40.1 & 49.4 & 35.6 \\
\hline SN5 & 14 & 70 & 30 & 1.5 & 0 & 35.6 & 52.7 & 40 \\
\hline SN6 & 16 & 30 & 70 & 1 & 1.31 & 45.8 & 47.7 & 30.8 \\
\hline SN7 & 16 & 40 & 60 & 1.28 & 0.94 & 44.7 & 49.4 & 32.3 \\
\hline SN8 & 16 & 50 & 50 & 1.39 & 0.61 & 45.2 & 50.2 & 32.3 \\
\hline SN9 & 16 & 60 & 40 & 2.22 & 0.45 & 43.4 & 50.8 & 32.5 \\
\hline SN10 & 16 & 70 & 30 & 2.14 & 0.14 & 35.6 & 50.9 & 33.5 \\
\hline
\end{tabular}

* Based on dry weight of residue 


\section{Pulp Strength}

To evaluate alkaline sulfite pulping behavior of corn stalks, pulps produced applying different sodium sulfite/sodium hydroxide ratios and 30 minutes pulping time, $145^{\circ} \mathrm{C}$ temperature, and $16 \%$ active alkali were selected for strength evaluation. Furthermore, in order to demonstrate the soda pulping performance on corn stalks, soda pulps produced applying either $12 \%$ or $18 \%$ active alkali, and 15 minutes pulping time at $145^{\circ} \mathrm{C}$ pulping temperature are evaluated. The results of handsheet strength testing are listed in Table 3. The influence of sodium sulfite/sodium hydroxide ratios on strength indices showed that at higher $\mathrm{NaOH}$ charge, the tensile and burst indices of the pulps improved, but its effect on tear index was not pronounced. Nevertheless, the tensile and tear strength values of soda pulps produced using $12 \%$ alkali were almost similar to alkaline sulfite pulps, but the tensile and burst strength values of pulp produced applying $18 \%$ alkali were somewhat higher, but at the cost of lower yield (Table 1). The results of statistical analysis on strength values showed that chemical charge significantly influenced strength. The Duncan ranking of the average values of strength measurement is shown in Table 3 (Superscript lower case letters denotes Duncan ranking at 5\% level).

In Table 3, our results are compared with data reported in the literature.

Table 3. Strength Properties of Alkaline Sulfite and Soda Pulps Produced from Corn Stalks

\begin{tabular}{|c|c|c|c|c|c|c|c|c|}
\hline \multirow{2}{*}{$\begin{array}{c}\text { Active } \\
\text { Alkali } \\
\%\end{array}$} & \multicolumn{2}{|c|}{$\mathrm{Na}_{2} \mathrm{SO}_{3} / \mathrm{NaOH}$} & \multicolumn{2}{|c|}{ Pulp Freeness } & \multirow{2}{*}{$\begin{array}{l}\text { Tear index } \\
\left(\mathrm{mN} \cdot \mathrm{m}^{2} \mathrm{~g}^{-1}\right)\end{array}$} & \multirow{2}{*}{$\begin{array}{c}\text { Tensile } \\
\text { index } \\
\left(\mathrm{N} . \mathrm{mg}^{-1}\right)\end{array}$} & \multirow{2}{*}{$\begin{array}{c}\text { Breaking } \\
\text { length } \\
(\mathrm{km})\end{array}$} & \multirow{2}{*}{$\begin{array}{l}\text { Burst index } \\
\left(\mathrm{kPa} \cdot \mathrm{m}^{2} \mathrm{~g}^{-1}\right)\end{array}$} \\
\hline & $\begin{array}{c}\mathrm{Na}_{2} \mathrm{SO}_{3} \\
\%\end{array}$ & $\begin{array}{c}\mathrm{NaOH} \\
\%\end{array}$ & Unrefined & Refined & & & & \\
\hline 16 & $\begin{array}{l}30 \\
40 \\
50 \\
60 \\
70 \\
\end{array}$ & $\begin{array}{l}70 \\
60 \\
50 \\
40 \\
30 \\
\end{array}$ & $\begin{array}{l}622 \\
606 \\
575 \\
575 \\
575\end{array}$ & $\begin{array}{l}436 \\
436 \\
422 \\
422 \\
411\end{array}$ & $\begin{array}{l}8.45^{a^{\text {*x }}} \\
9.88^{a b} \\
10.53^{b} \\
9.75^{a b} \\
9.83^{a b}\end{array}$ & $\begin{array}{l}62.6^{b} \\
63^{b} \\
62.4^{b} \\
53.2^{a} \\
55.5^{a}\end{array}$ & $\begin{array}{l}6.39^{\mathrm{b}} \\
6.43^{\mathrm{b}} \\
6.07^{\mathrm{ab}} \\
5.43^{\mathrm{a}} \\
5.66^{\mathrm{ab}} \\
\end{array}$ & $\begin{array}{l}3.38^{a} \\
3.81^{a} \\
3.80^{a} \\
2.60^{a} \\
2.84^{a}\end{array}$ \\
\hline $\begin{array}{l}12 \\
18\end{array}$ & - & $\begin{array}{l}100 \\
100\end{array}$ & $\begin{array}{l}588 \\
629\end{array}$ & $\begin{array}{l}333 \\
333\end{array}$ & $\begin{array}{l}9.40 \\
9.95\end{array}$ & $\begin{array}{l}62.17 \\
72.74\end{array}$ & $\begin{array}{l}6.54 \\
7.41\end{array}$ & $\begin{array}{c}4.5 \\
5.47\end{array}$ \\
\hline $6.6^{1}$ & & 100 & & 180 & 3.5 & & 5.61 & 4.4 \\
\hline $7^{2}$ & & 100 & & & 8.8 & 44.5 & & 2.5 \\
\hline $22^{3}$ & & 100 & & 480 & 5.07 & 24 & & 1.22 \\
\hline $14^{4}$ & & 100 & & 350 & 4.7 & 71 & & \\
\hline $\begin{array}{c}\text { Mixed } \\
\text { hardwoods }^{5}\end{array}$ & & & & 350 & 8.1 & 73 & & - \\
\hline $\begin{array}{l}\text { Recycled } \\
\text { fiber pulp }^{6}\end{array}$ & & & & $42^{*}$ & 9.05 & - & 3.37 & 2.18 \\
\hline
\end{tabular}

* SR

** The lower case letters indicates Duncan ranking of the averages

1- Bivis technology wheat straw CMP, Petit-Conil et al. 2001

2- With enzyme pretreatment, poplar CMP, Boeva-Spiridonava et al. 2007

3- Canola soda, pulping time; 100 minutes at $170^{\circ} \mathrm{C}$, Enayati et al. 2009

4- Data extracted from graphs, Corn stalks, EAZP process, Byrd and Hurter 2005

5- Data extracted from graphs, Byrd and Hurter 2005

6- Petit-Conil et al. 2001 
The strength values of the alkaline sulfite pulps produced using corn stalks were superior to CMP pulp from wheat straw (Petit-Conil et al. 2001), CMP pulp from poplar wood applying enzyme treatment (Boeva-Spiridonava 2007), canola soda (Enayati 2007), and recycled fiber pulps (Petit-Conil 2001).

\section{DISCUSSION}

The length of the fibers $(1.03 \mathrm{~mm})$ from corn stalks is in the range of hardwoods and other agricultural residues such as bagasse, $1.13 \mathrm{~mm}$ (Sanjuan et al. 2001), but shorter than wheat straw, $1.73 \mathrm{~mm}$ (Mckean and Jacobs 1997) and $1.5 \mathrm{~mm}$ (Mohan et al. 1988), and date palm tree rachis fibers (1.3 mm) (Khristov et al. 2005). The Runkel coefficient of corn stalks fibers $(0.58)$ is less than either wheat straw $(0.67)$ or bagasse $(0.67)$ as well as date palm rachis $(0.8)$ and leaves $(0.9)$ (Khristova et al. 2005), but the flexibility coefficient of corn stalks fibers $(0.78)$ is higher than that of either date palm rachis and leaves and bagasse (Sanjuan et al. 2001). This indicates good sheet formation potential of these fibers. However, the felting coefficient is not as good as date palm residues.

Both cellulose and lignin content of this material is comparable to softwood and hardwoods. However, it is higher than most of the agricultural residues (Sanjuan et al. 2001; Mckean and Jacobs 1997).

The performance of corn stalks in alkaline sulfite and soda pulping process varies considerably, and usually low yield is reached. Even though it was possible to reach the total yield between lowest value of $42.5 \%$ and highest value of $61.9 \%$ by changing the pulping temperature and chemical charge, achieving higher yield is difficult with this material. The highest total yield of soda pulps from corn stalks was measured as 43.2\% (kappa number of 57.9). Applying different sodium sulfite/sodium hydroxide ratios at either $14 \%$ or $16 \%$ active alkali was influential on total yield and at lower $\mathrm{NaOH}$ charge, the total yield and kappa number improved, which indicates the vulnerability of corn stalks toward alkaline chemicals. Comparing our data with non-wood pulping results reported in the literature supports our finding. E-stage yield of EAZP process developed by Byrd and Hurter (2005) was $57.9 \%$ (kappa number of 20.1 ) and for soda/AQ was measured as $55.1 \%$ (kappa number of 32.9). Enayati et al. (2009) applying soda pulping $\left(22 \%\right.$ active alkali, $170^{\circ} \mathrm{C}$ pulping temperature and 100 minutes time) on canola residues reported the pulping yield of $36.9 \%$ to reach a kappa number of 24.2 .

Since the objective of this study was to produce suitable pulp for unbleached paper production or utilization of the pulp as a substitute for recovered brown stock (recycled old corrugated container), the pulps produced applying different sodium sulfite-sodium hydroxide ratios and $16 \%$ active alkali were selected for further evaluation. Pulps were refined to about $410 \mathrm{ml} \mathrm{CSF}$ and handsheets were made. Changing the ratio from 30:70 to 70:30 (lower dosage of $\mathrm{NaOH}$ ) increased the tear index from 8.45 to $9.83 \mathrm{mN} \cdot \mathrm{m}^{2} \mathrm{~g}^{-1}$, and reduced breaking length from 6.39 to $5.66 \mathrm{~km}$, burst index from 3.81 to $2.84 \mathrm{kPa} . \mathrm{m}_{2} \mathrm{~g}^{-1}$ and tensile index from 62.6 to $55.5 \mathrm{Nmg}^{-1}$. The respective tear, tensile, and burst indices and breaking length of soda pulps applying $18 \%$ active alkali were measured as $9.95 \mathrm{mN} . \mathrm{m}^{2} \mathrm{~g}^{-1}, 72.7 \mathrm{Nmg}^{-1}, 5.47$ $\mathrm{kPa} \cdot \mathrm{m}^{2} \mathrm{~g}^{-1}$, and $7.41 \mathrm{~km}$, respectively. To investigate the performance and suitability of alkaline sulfite pulps, we have compared our results with similar research results 
reported in the literature (Table 3). The information demonstrated the superiority of alkaline sulfite pulps compared to wheat straw CMP produced on BiVis technology, applying $6.6 \%$ active alkali as well as unbleached canola soda pulp, corn stalks soda/AQ, mixed hardwoods, and recycled fiber pulp. Something to our surprise was the very high strength value of pulps produced from corn stalks. Even though the 1\% $\mathrm{NaOH}$ solubility of this material is high, which causes lower pulping yield compared to wood and some other non-woods such as wheat straw, the strength values were considerably higher due to better flexibility of its fibers and the presence of low molecular weight carbohydrates. This implies its suitability for unbleached pulp production, as supplementary pulp for recycled fibers.

\section{CONCLUSIONS}

The world paper industry, which is under pressure from environmentalists, is searching for alternative raw material for future fiber supply. The situation in fiberdeficient countries, especially in the Middle East, is so severe that these countries cannot develop a national paper industry based on wood fibers. Therefore, different research groups have been looking at alternative fiber resources, including wheat straw, sunflower stalks, as well as corn stalks, as investigated in this study. Fiber dimensions and chemical composition of corn stalks were measured. Then alkaline sulfite pulping trials were performed, applying different chemical charges and pulping temperatures. The results indicated that corn stalks are suitable for this type of pulping, and application of $16 \%$ active alkali, 30 minutes pulping time at $145^{\circ} \mathrm{C}$ pulping temperature, and sodium sulfite/sodium hydroxide ratio of 50:50 will generate pulp suitable as supplemental pulp for unbleached paper production. Tensile index, breaking length, burst index, and tear index of this pulp $(50.2 \%$ total yield) were measured as $62.4 \mathrm{~N} \cdot \mathrm{mg}^{-1}, 6.07 \mathrm{~km}, 3.80 \mathrm{kPa} \cdot \mathrm{m}^{2} \mathrm{~g}^{-1}$, and $10.53 \mathrm{mN} \cdot \mathrm{m}^{2} \mathrm{~g}^{-1}$. Based on the findings of this study, alkaline/sulfite pulping this raw material will open new way for utilization of this unused material, to fulfill the pulp fiber shortage in fiber-deficient countries.

\section{ACKNOWLEDGEMENTS}

The agriculture research center of Islamic Azad University, Karaj Branch provided financial support which we ought to appreciate. Iran Standard and Industrial Research Organization, Packaging Dept. is gratefully acknowledged for testing facilities.

\section{REFERENCES CITED}

Ali, S. H., Asghar, S. M., and Shabbir, A. U. (1991). "Neutral sulfite pulping of wheat straw," In proceedings of the TAPPI Pulping Conference, TAPPI Press, Atlanta, GA, USA, 51-56. 
Ates, S., Atik, C., Ni, Y., and Gumuskaya, S. (2008). "Comparison of different chemical pulps from wheat straw and bleaching with xylanase pre-treated TCF method," Turkish J. Agric. For. 32, 561-570.

Boeva-Spiridonova, R., Petkova, E., Georgieva, N., Yotova, L., and Spiridonov, I. (2007). "Utilization of a chemical-mechanical pulp with improved properties from poplar wood in the composition of packaging papers," BioResources 2(1), 34-40.

Braunstien, R. (2002). "Pulping and bleaching of SAS-AQ bagasse pulps," In: Proceedings of the African Pulp and Paper Week-Adding Value in a Global Industry, South Africa, Durban.

Byrd, M. V., and Hurter, R. W. (2005). "A simplified pulping and bleaching process for pith containing nonwoods: Trials on whole corn stalks," TAPPI Fall Technical Conference, $10 \mathrm{pp}$.

Enayati, A. A., Hamzeh, Y., Mirshokraei, S. A., and Molaei, M. (2009). "Papermaking potential of canola stalks," BioResources 4(1), 245-265.

Franklin, G. L. (1954). "A rapid method for softening wood for anatomical analysis," Tropical Woods 88, 35-36.

Hedjazi, S., Kordsachia, O., Patt, R., Jahan Latibari, A., and Tschirner, U. (2008a). "Bagasse alkaline sulfite-anthraquinone (AS/AQ) pulping and totally chlorine free (TCF) bleaching," Holzforschung 62, 142-148.

Hedjazi, S., Kordsachia, O., Patt, R., Jahan Latibari, A., and Tschirner, U. (2008b). "Alkaline sulfite-anthraquinone (AS/AQ) pulping of wheat straw and totally chlorine free (TCF) bleaching of pulps," Ind. Crops Prod. 29, 27-29.

Hedjazi, S., Kordsachia, O., Jahan Latibari, A., and Tschirner, U. (2009). "Alkaline sulfite/anthraquinone (AS/AQ) pulping of rice straw and TCF bleaching of pulps," Appita J. 62(3),137-145.

Jahan Latibari, A., Fakhrianroghani, A., Sepedehdam, S. J., and Aliakbarpour, M. H. (1996). "Investigation on paper making properties of corn stalks," Pajouhesh Va. Sazendegi 32, 45-49 ( In Persian).

Kordsachia, O., and Patt, R. (1991). "Suitability of different hardwoods and non wood plants for non-wood pulp production," Biomass Bioenergy 1(4), 225-231.

Kristova, P., Kordsachia, O., Patt, R., Khadir, T., and Karrer, I. (2002). "Alkaline pulping with additives of kenaf from Sudan,” Ind. Crops. Prod. 15, 229-235.

Khristova, P., Kordsachia, O., and Khider, T. (2005). "Alkaline pulping with additives of date palm rachis and leaves from Sudan," Bioresource Technol. 96, 79-85.

Law, K., Lanoutte, R., and Mana Sarr, N. D. (2003). "Characterization of kenaf by chemimechanical pulping solutions," Tappi J. 2(6), 14-18.

MacGoven, J. N., Coffett, D. E., Hurter, A. M., Ahuja, N. K., and Wiedermann, A. (1987). "Non wood pulping," In: Pulp and Paper Manufacture. Vol. 3. Secondary Fibers and Non-Wood Pulping, Hamilton, F., Leopold, B., and Kocurek, M. (eds.), TAPPI Press, Atlanta, GA, USA.

Mckean, W. T., and Jacobs, R. S. (1997). "Wheat straw as a paper fiber source," Unpublished report, The Washington Clean Center, Seattle, WA, USA, 47 pp.

Mohan, R., Prasad, R., Yadav, R., Ray, K. K., and Rao, N. J. (1988). "Pulping studies of wheat straw using soda and soda-anthraquinone processes," First International Non-Wood Pulping Conference, Beijing, p. 339.

Pan, G. X., and Leary, G .L. (2002). "Alkaline peroxide mechanical pulping of wheat straw, Part 1: Factors influencing the high brightness response in impregnation," Tappi J. Peer Reviewed, 9 pp. 
Pande, H. (2009). "Non-wood fiber and global fiber supply," Unisyva, No. 193, 9 pp.

Petit-Conil, M., Brochier, B., Labalette, F., and Combette, P. (2001). "Potential of wheat straw to produce chemimechanical pulps suited for corrugating papers manufacture," TAPPI 2001 Pulping Conference, 11 pp.

Sanjuan, R., Anzaldo, J., Vargas, J., Turrando, J., and Patt, R. (2001). "Morphological and chemical composition of pith and fibers from Mexican sugarcane bagasse," Holz als Roh und Werkstoff 59, 445-447.

TAPPI Standards and Suggested Methods (2008). TAPPI Press, Atlanta, GA, USA.

Xu, E. C., and Rao, N. N. (2001). "APMP (Alkaline peroxide mechanical) pulps from nonwood fibers. Part 3: Bagasse,” In: Proceeding of the TAPPI 2001 Pulping Conference, $6 \mathrm{pp}$.

Wang, D. L.-K., and Patt, R. (1989). "Alkaline sulfite-anthraquinone pulping of bagasse," Holzforschung 43(4), 261-264.

Article submitted: July 4, 2010; Peer review completed: Oct. 24, 2010; Revised version received and accepted: Oct. 28, 2010; Published: November 3, 2010. 